\title{
Sociological Reconceptualization of Social Development: With Empirical Evidence from Surakarta City, Indonesia
}

\author{
Paulus Wirutomo ${ }^{1}$ \\ ${ }^{1}$ Department of Sociology, Faculty of Social and Political Sciences, University of Indonesia, Indonesia \\ Correspondence: Paulus Wirutomo, Department of Sociology, Faculty of Social and Political Sciences, \\ University of Indonesia, Depok, 16424, Indonesia. Tel: 62-21-7884-9025. E-mail: paulus.wirutomo09@ui.ac.id
}

Received: February 10, 2014 Accepted: March 25, 2014 Online Published: May 30, 2014

doi:10.5539/ass.v10n11p283 URL: http://dx.doi.org/10.5539/ass.v10n11p283

\begin{abstract}
After more than six decades, the growth-oriented development strategy has failed to develop people's essential well-being, social equality and better quality of socio-cultural life. United Nations called it: jobless, ruthless, rootless, voiceless, and futureless growth (UNDP, 1997). Recently, several new development approaches has been introduced, such as People-Centered Development, MDGs, Human Development, but those approaches are proposing more for the enhancement of some "social sectors", rather than being oriented into developing a "good society". Herewith, in this article a more sociological conceptualization of social development is introduced by emphasizing that developing human being has to be done through developing the basic elements of social life, namely structure, culture and process of the society. The purpose of this paper is to propose and discuss the new and the more sociological concept of social development. An action research has been conducted to explore some empirical evidence of social development practices implemented in Surakarta city as an illustration.
\end{abstract}

Keywords: culture, informal sector, process, social development, sociology, structure

\section{Introduction: The Crisis of "Developmentalism"}

The growth-oriented development concept has failed in developing people's essential well-being, social equality, inclusiveness and ultimately good society. Despite producing economic growth, this approach has created a jobless growth (unable to provide sufficient and dignified employment), ruthless growth (growth that is producing poverty and increasing social gaps), rootless (un-rooted economic development to local community and destroying the local tradition and cultural values), voiceless (no people's aspirations are heard, undemocratic and non-participative) and futureless (destroying the environmental sustainability) (UNDP, 1997). Moreover, Korten (1990) has identified that the development approach has produced three major global crises: violence, poverty, and environmental damage.

This so called "developmentalism" is too much technocratic, too materially oriented, perceive human beings as "one dimensional" and reduce them as an "object" of development. Therefore, in the future the role of social sciences should be more prescriptive and inspiring to the basic direction of development. It should be able to balance the strong materialistic drive of development model with the aspiration toward the quality of socio-cultural life (such as social inclusiveness, equality, social harmony, justice, freedom, and even happiness) as their developmental targets. Hence, we definitely need a more sociologically substantive, clear cut, workable and measurable Social Development concept.

\subsection{What Is Social Development?}

The World Summit for Social Development in Copenhagenin 1995is a good sign of Global attention on the issue of Social Development. This summit saw eradication of "poverty" as a central issue.It should be argued however, that besides "poverty" the existing development approach as also produced so many other destructions to socio-cultural life of human kind such as, violence, terrorism, exploitation and discrimination to the minority and so on. This all happen because the existing Development practices has excluded some people from their basic rights as members of society. That is why inclusive socio-cultural life must instead, be the basic target of socio-cultural development, material poverty is only a part of the problem.

Reviewing the existing concepts of Social Development shows us this following picture. Social Development is perceived as the provision of basic social services (Kamerman \& Khan, 1979), social work for Community 
Development (Payne, 2005), enhancement of people participation, equity, sustainability, social integration, human rights (United Nation, 1999), individual improvement such as self-actualization, entrepreneurship, capacity building (Midgley, 2003). "People centered paradigm" emphasizing on building Human Societal Capabilities such as human capital, social capital and cultural capital (Aspalter, 2006; Korten, 1990), improvement of the achievements of some "social sectors" (MDGs), the bringing back indigenous culture as the basis of Development (Sukamoto, 2003). In short, Social Development is a planned change toward optimal development of the people, enable them to effectively perform their social role to achieve greater happiness, satisfaction, and a peaceful life (Siddiqui, 1964; Kulkarni, 1998, 1999; Singh, 2004 in Aspalter 2006). Social development, is a highly flexible concept, which in itself carries the seeds of its own success and pitfalls at the same time (Luhman, 1998 in Aspalter 2006).

Basically all those proposed elements of Social Development are indeed important contributions to balance the emphasis of existing economic-biased development, but in general those conceptualization are still very "partial" (non systemic) and "residual" (emphasizing only some "social sector" such as health and education).We need a more sociological certainty that those programs are producing real impacts on the basic elements of socio-cultural life (structure-culture and process).

James Midgley, the writer of "Social Development" somewhat "pessimistic" about this concept, he pointed out:

".....social development perspective is not widely known in industrial countries today nor is it generally accepted in academic circles....the field is still theoretically underdeveloped, and there is much confusion about what social development entails in programmatic terms." (Midgley, 1995: 7).

He defined social development as:

".. a process of promoting people welfare in conjunction with a dynamic process of economic development" (Midgley, 1995: 8)". He also mentioned:"Social development depends on the integration of the economic and social domain or combining diverse strategies for the promotion of social welfare". (Midgley, 1995: 9).

What did Midgley means by "in conjunction with"? He seems to believe that social development could go hand in hand with economic development. However, the "conjunction" may not only be a politically trivial lips service or just to compromise or to adjust socio-cultural interests to economic one. Wirutomo has argued that social and economic domain is essentially belongs to the same domain i.e. socio-cultural life of a society (Wirutomo, 2011). Hence, any developmental endeavor must be rooted in the same purpose that is the improvement of the quality of "socio-cultural life". To achieve that, we definitely need a social development concept which simultaneously covers the improvement of all basic elements of socio-cultural life namely the structural aspect (the pattern of power relations), cultural aspect (the internalized values, norms, traditions) and processual aspect (the dynamics of everyday interactions among people, the quality of public sphere in which people could express their aspiration).Social development is not simply a result of compromise between social and economic "sectors", but a systemic and holistic development where all sectors are unified. This is the way to locate socio-cultural aspect in its right position.

As an improvement of the quality of socio-cultural life, the ultimate goal of Social Development is to achieve an inclusive society. The concept of inclusion refers to the provision of opportunity to all members of society to get fundamental rights and material as to enable them to participate in all aspects of socio-cultural life (Giddens, 2009; Harolombos, 2008). Inclusiveness is not simply a catering of better provision of social services or physical resources through the government policies, but also the development of people's potentials to create an emancipatory socio-cultural life (a good society). Thus the socially inclusive development is more comprehensive and more fundamental than just poverty elimination which has often been the main issue of recent development policies (Conyers, 1982; Midgley, 1995). Therefore, any sectoral aspect of society (be it economy, physics, law, religion etc.) must be structurally-culturally-processually developed and must be oriented toward inclusive value system (value-based development).

\section{Conceptual Framework}

The more "sociological" approach of development is inspired by Bellah statement:

"It is difficult to be a good person in the absence of good society. The difficulty actually comes from failures of the larger institutions on which our common life depends". (Bellah, 1992: 4). In line with this statement, Wirutomo argued that to develop human being we have to develop their society systemically and holistically instead of just concentrating on the "social sectors" such as education, health (Wirutomo et al., 2011; Wirutomo, 2012).

Every human society is based on the system of interaction and interrelation (Note 1) which forms a "social life". 
Thus, every development must be directed to fundamental or basic elements of "social life" namely: "culture, structure and social process". Hence the concept of socio-cultural development has more fundamental sociological meaning, not merely "socio-cultural sectors" development. The specific notification of "social development" is not intended to polarize with economic development, to separate both practices, or even perceive them both as mutually exclusive choices. As a matter of fact, economic life is essentially a socio-cultural life (in Marx's words: “...social relation of production"), so that social development must be considered as the basis or root of economic and other sector's development (see Figure 1).

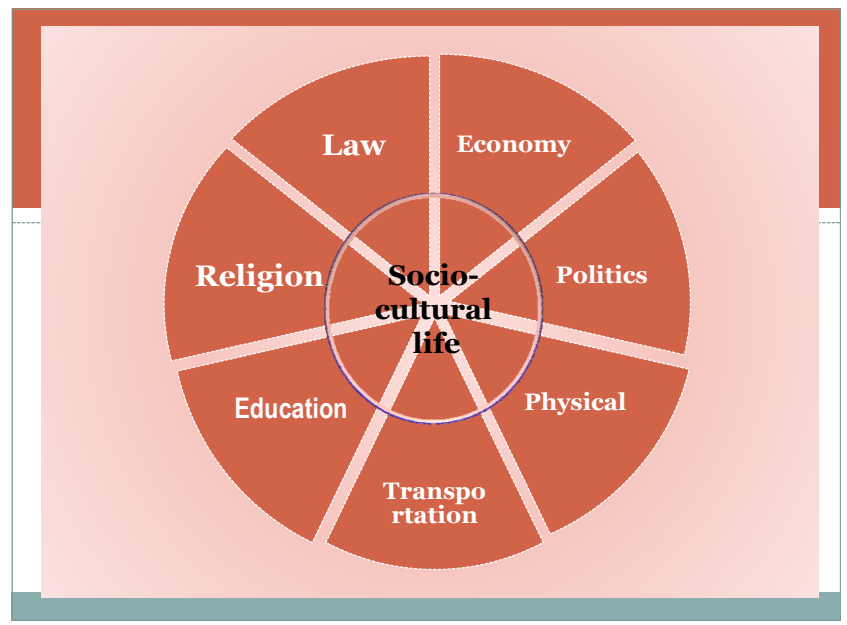

Figure1. Development "sectors" and socio-cultural life

In order to produce "a genuine social well-being", all aspect or "sector" of development (economic, physical and others) must be directed to improve the quality of basic elements of social life i.e. the structural, cultural and processual aspects. The picture above indicates that socio-cultural life must be considered as the central goal of Development, it does not constitute as "sector" (like education, health and others) (Note 2), but it is the root of every sectors. It will give sense of direction and common values to all sectors about the direction of the national development endeavor. Every sector, thus may no longer concentrate only on its specific "sectoral" targets.

As a consequence of the above principle, it is not sufficient to evaluate developmental efforts just from the existing sectoral programs, but we need to see the impact of the programs more sociologically on the structural, cultural and processual level. In other words, how far the quality of socio-cultural life is improved in reality. The lack of a clear sociological impact of social development downplays the ideological commitments and creates confusion about its goals.

\subsection{Basic Element of Social Development: Structural Element}

Structure, culture and process are the basic elements of social life in society. Social structure is basically a pattern of relation (particularly power relation) among individual or social groups that coercively and imperatively constrains and regulates the interactions and interrelations in society (Marx, 1967; Dahrendorf, 1959).The Social structure is maintained by "structural forces" either through the legal-formally institutionalized ones such as legislations, government regulations etc., or non formally or extra-legally institutionalized ones, such as influential power of business world (Note 3). This possession of structural power is often monopolized by the elites (e.g. the state in collaboration with big corporate) to build structural domination pattern that oppress people and exploit their economy. Thus, the structural development means improving the balance of power relation between the government and the common people or between the rich and the poor, through the development policy, legislation, development budget and other structural powers that benefits the majority or modify the exclusive (unjust, discriminative) structure into inclusive one. Otherwise, "development" tends to make society more and more unequal (exclusive society). The "trivial" provision of social services (not involving structural changes) will only create "false consciousness" among the people. The challenge is how to find indicators which indicate a structural change or development.

\subsection{Basic Element of Social Development: Cultural Element}

Culture here is defined specifically in its purely subjective terms as: system of values, norms, beliefs, customs as well as traditions internalized by individuals, communities or all members of society, thereby it forms the 
pattern of behavior and attitudes from "inside". Social structure could be considered as culture, but Harrison in "Culture Matters" argued: “..if culture includes everything, it explain nothing” (Harrison, $2000 \mathrm{p} x \mathrm{x})$. Thus, in this article for the sake of analysis, those two concepts are differentiated. The most important distinction between structural power and cultural power is in its level of internalization. The structural power is based on institutionalization of regulations or norms, meanwhile the cultural power is based on internalization of values and norms in the system of personality of an individual or in the social system. It includes what Durkheim (1961) has categorized as "the sacred", Bourdieu (1992) has named it "habitus".

The existing culture however, is not always the best way of living that guarantee the well-being of the people. The powerful groups try to conserve the existing culture to protect their own interests and oppress other groups through "cultural hegemony". So, the quality of power relations in society is not only structural but also cultural construction. Thus, a cultural development program is needed to improve the quality of society's system of values and customs that inhibit their prosperity or manipulate them directly or indirectly, through the development of social structure and process.

In sociological theory - as contrast to anthropology - the importance of culture is very often "underestimated" against "the structure". Without the tendency to adopt "cultural determinism", it is very important to see culture as one of the most important basic elements of society, following the tradition of Durkheim $(1938,1961)$, Weber (1958, 1963), Parsons (1951) and some contemporary sociologists like Huntington, David Landes, Fukuyama, Pye and Harrison (2000) who questioned:

"To what extent do cultural factors shape economic and political development? If they do, how can cultural obstacles to economic and political development be removed or changed so as to facilitate progress?". (Harrison, 2000)

Cultural element of social development has been recently rediscovered, namely that of cultural capital. The study of cultural capital has been almost forgotten over the past three and a half decades, even though a great deal of research was provided by Pierre Bourdieu on the subject (Bourdieu, 1997, 1983; Bourdieu \& Passeron, 1970).

\subsection{Basic Element of Social Development: Social Process Element}

Social process is the dynamics of the informal and day today interactions among society members which has not yet been formally structured or cultured. Through "fluid" social processes, individuals or groups more freely express, discuss, negotiate their aspirations, dynamically and creatively. This "open arena" is the source of changes of the existing structure and culture. Basically "social order is a negotiated order". Some illustrations of social process are: daily social interaction, the participation in social network, clubs, associations, the emergence of social trust, communication, collaboration, disputes, conflicts, civic activism, public sphere etc. In sociological theory, this "processual" element is the central analytical subjects of "symbolic interactionism, ethnomethodology, constructivism, post structuralism (Foucault, Lacan, Derrida) and post modernism (Baudrillard, Lyotard, Jameson). Hence, it is argued that developing "social process" means developing a larger "opportunities" for the people to express their aspirations and opinion through providing public space and developing public sphere (see also Habermas, 1984).

This holistic analytical approach is an important contribution to the building of Social Development concept. Sociologically it covers all basic elements of social life. Moreover it simultaneously accommodates all perspectives within Sociology: the structuralist, the culturalist and the interpretive perspective. This approach itself is on the stream of integrationist (Giddens, 1987; Bourdieu, 1992). It should be noted that in real life, structure, culture, and social process at some degree cross-cut, influence each other and embedded to form a complex system that must be studied holistically rather than separately (see figure 2). 


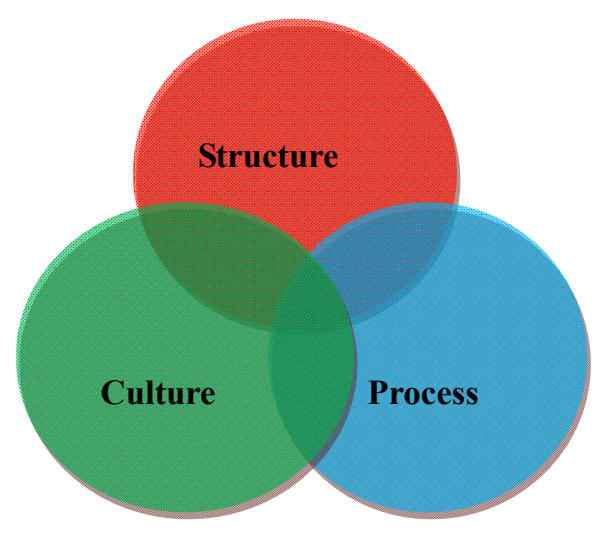

Figure 2. Fundamental elements of a social life

\subsection{Cross-Cutting Element of Social Development}

The cross-cutting elements produce some "cross section areas" which show how the "Structure-Culture-Process" are interacting and merging one another producing different conditions of Social Development. First, the cross-cutting between the Structural and Cultural elements produces two symptoms, those are: (a) Cultured Structure (CS) e.g. the government regulations which are well internalized to become part of people's culture, (b) Structured Culture (SC) i.e. cultural elements that are being "promoted" or legalized to become formal regulations.

Second, the cross-cutting between Structure and Process produces two phenomena, those are: (a) Structured Process (SP) namely some daily interactions are being promoted into formal regulation; (b) Processed Structure (PS) i.e. government regulations which are put into discourse or being re-negotiated by the people through daily interactions.

Third, the cross-cutting between Culture and Process produces: (a) Processed Culture (PC) i.e. the questioning and renegotiating of traditions or value system by the people through daily interactions; (b) Cultured Process (CP) i.e. the practice of daily interactions which are internalized and become cultural element.

Fourth, the "total" cross-cutting between Structural-Cultural and Processual elements which is showing an ideal coherence of a social unit from the micro level (individual), the mezzo level (community or organization) to the macro one (society, national or global).

\section{Empirical Evidence: Social Development Practices in Surakarta City (Note 4)}

Surakarta City (Note 5) was selected as a case, because of its well known reputation as the best city development in Indonesia. The social development practices in Surakarta have been studied through its three basic elements namely structural, cultural, and processual development.

\subsection{Research Method}

This research was a qualitative approach. The collection techniques are document study: from vision-mission to various Development policies, regulations, budget, in-depth interview: were done to Government officers (form the Mayor to field officers), the street vendors. FGD were done to confirm the data, it was conducted to Government officers to street vendors, experts and NGO's members. Observations were done systematically through audio-visual recording and field note-keeping.

\subsection{Research Findings}

\subsubsection{Structural Development}

The social development in Surakarta City is actually rooted in Mayor Jokowi's value system of "inclusive" economy which he promoted during political campaign when he runs as a mayor candidate. When Jokowi was elected as Mayor, the value system was further translated into the official vision and mission of Surakarta. The vision is: "To improve the prosperity of the people and to develop the city based on the spirit of Surakarta as a Cultural City". One of the inclusive-oriented missions is: 
"To develop and improve people-centered economy through real sector development, micro-, small-, and medium-business empowerment, and credit-facilitated-cooperative development; to train the street vendors management; to continue the traditional market revitalization program; to improve market traders' managerial skills; and to promote the existence of (traditional) markets and traders" (Wirutomo, 2011).

All those formal formulation are manifestation of "structural" development since it transforms" power relation" among group in society through new regulative instruments. This is also a "structured culture" (SC) phenomenon, where inclusive value system of Jokowi is being incorporated into structural element (an officially formulated vision and mission) (Note 6). Next step, Jokowi's administration has consistently translated the vision-mission into some other structural re-arrangement: (a) a policy that shopping center and mall development is not a priority, while the street vendors (PKL) accomodation is the top priority; (b) the implementation of street vendors empowerment is done in accordance with the effort to promote Solo as an eco-cultural city; (c) budget restructuration is done to support the implementation of street vendors relocation program; (d) dialog is the best way to communicate the program, any form of repressive action is not allowed; (e) various forms of PKL relocation program management has been set up, including budget restructuration, formulation of SOP, Implementation Manuals and Technical Guidelines, and data collection. Series of formal and informaldialogues - individual and institutional — as well as dialogues with the community representatives have been conducted as an important part of the program implementation as a whole.

The city government gives opportunities tothe powerless actors (informal sector)to obtainspace to trade through relocationpolicy. Using structural power (regulation), the government managed relocation program through: (1) providing free stalls (2)setting up Vendors' Cooperatives to help them financially independent,(3) provision of Trade or Business License (SIUP) to the relocated street vendors, Company Registration Certificate (TDP), Certificate of Placement Right (SHP) and Street Vendor Identification Card (KTPP), so that their status was changed from informal sector traders into formal ones; (4) apart from that, local government had provided space choices/business stalls for street vendors, i.e.: shelter, tent (in sidewalks and streets, with limited time), and push-carts.

The relocation program, as a structural treatment, had also triggered processual and cultural aspects. The street vendors as citizen learn their obligation to move out from the illegal space, but in reverse they get their rights to do their business with affordable facilities. (Note 7)

\subsubsection{Cultural Development}

As what have been discussed earlier, cultural development in Surakarta is marked and driven significantly by the policy of Eco-Cultural City. The considerations are, among others, to provide cultural orientation for Surakarta in order to develop its city identity. Nowadays Surakarta is undergoing a significant cultural degradation. The old Surakarta was characterized by fine traditional culture that local people are proud of. That's why "colloquially" the Mayor said that "the future of Surakarta is the old Surakarta".

The revival of the city's traditional culture is encouraged by conservation of old traditions. Traditional art performances are promoted in Surakarta calendar of events. Government officials are instructed to dress Javanese at the offices on certain days, traditional ornaments are displayed in every corners of protocol streets etc. This "cultural revitalization" program has created a new cultural atmosphere in Surakarta which directly or indirectly also stimulates the street vendors' cultural appreciations. In the past, street vendors did not care about "city culture", they were busy with basic material needs, no such cultural appreciations. Now, they realize that their stall must somewhat contribute to city beautification program.

The provision of free stall to the vendors has induced a more positive attitudes and behavior of the traders in the civic life, such as: participation in the professional organization, development of social control mechanism among street vendors, the formation of "merchant" mentality among them. Some new value system have also developed cleanliness and attractiveness values, through organized activities of decorating the market building; creativity values, through the joint art events for promotion and responsibility values. All of this evidence means that a regulation that provides physical facilities (physical structure) could encourage cultural changes.

Cultural revitalizationprogram is a structural development which could stimulate the process of internalization of several cultural values. This structural efforts of government hadeventually resulted in new cultural excitements of the peoplein general as well as among the street vendors.

\subsubsection{Processual Development}

Tosupport the development programs in Surakarta, Jokowi is very aware of the processual power.Jagongan(a traditional social gathering) has been chosen by Mayor Jokowi to build aninformalcommunication (social 
process) with the vendors through which both parties could negotiate informaly to find the concensus on the concept of city's civic order.Thisparticular practice has shown various combination of Structural-Cultural and Processual elements. The use of traditional gathering as an official government'sprocedure is a "Structured Culture (SC)", on the other hand the practice to accommodate the informal social process into the formal standard operation procedure (SOP) of the Government is a phenomenon of "Structured Process"(SP). Eventhough this traditional approach seems inefficient (conducted 54 times), it was eventually very effective.

The structural treatment of city government to relocate the street vendors to Klithikan market has also created some interesting social processes. The city mayor no longer call them "street vendors" but "merchants", because they already have permanent place, and not being chased by the police. The change of status had in fact given the vendors higher self esteem. A street vendor said:

"... in the past, I was more afraid of the rain than the Police (Satpol PP), because when it was raining, I have to clear out my selling goods. Now, I don't have to. My family, even, can stop by here, just like visiting their father's office. Previously, such thing was impossible, besides dirty, the place was "unclean" mixed with the drunkards, prostitutes, and the like ..." (Wirutomo, 2011)

The status as "merchant" also stimulates certain positive mental attitudes of the traders. They build some new pattern of interaction with their social surrounding, such as more actively participating in business network, creatively explore new activities to improve their business, and keep theirmarket clean. This processual improvement will gradually become cultural (Cultured Process).

Jokowi likes to make incognito visitto the market by riding bycicle and converswith the traders casually. Such communication style might still be very personal and processual,but this personal style now become popular among the city officers so in the future it could become an "official"standard of communication procedure(StructuredProcess).

The Mayor's instruction to the police (Satpol PP) of not practicing violent approach in regulating the street vendors hadalso encouraged some interesting social processes. Without being armed with violent tools in doing their job, the Satpol PP were forced to regulate the street vendors in an alternative way. As a replacement of police batons, they have to carry a pocket book of Local Regulation on Street Vendors. With the pocket book in their hand theyplay the role as an agent of socialization about local regulation among the street vendor community so they are "forced" to develop their persuassive and even teaching skills. Here the "Structure" has improved the quality of social process (social interaction)between Satpol PP and the street vendors. This practices is in compliance with the traditional value system of "nguwong kewong" (treat human as human), so this traditional value system become a cultural guideline for the implementation of formal regulation (Structured Culture). Altogether, this is a picture of a "Structure-Culture-Process" dynamic interaction.

The head of Satpol PP stated that they are not only establishing the local regulation, but through more intensive interpersonal communication, they better recognized the difficulty of the vendors in the field more than any other government officials. Thus, in Surakarta Satpol PP has been functioning as problem solver, building a more innovative and peaceful system, rather than forcefully evicting the street vendors.

This "attitudes building"is an important element of socio-cultural development namely improving the quality of interaction. In this case, we find a sociological process as Giddens named it "structuration"where values underlies structure, creating and facilitating new process, confirming and establishing new culture (Bourdieu's habitus),in general this is the basic or ultimate goals of "Social Development" namely creating "good" society (Bellah, 1992).

Another aspect of social Process that Mayor Jokowi paid attention is to provide public space in order to enhance the dynamics of civic expression (public sphere) (Habermas, 1984). The public sphere is built by Jokowi not only through providing physical space, but also by giving opportunity to the people to access them, so people could gather, greet each other and thus improved the quality of civil interactions including toexpress their political opinion, facilitating art and cultural expression etc.

Public space and public sphere are closely related, but public sphere is sociologically more important for building the quality of social process. Jokowi realize that essentially "development is a Process". This is the basic weakness of "technocratically planned Development" which relies too much on structural power determined almost one-sidedly by the authorities.

\section{Theoretical Reflection: Why Structure-Culture-Process?}

By putting forward the basic elements of socio-cultural life as the center of Development endeavor, this new conceptual approach is intended to liberate human society from materialistic, sector oriented and growth oriented 
Development. All development sectors must be rooted and oriented to the basic values of social inclusiveness through the improvement of the quality of the basic element of socio cultural life namely: the Structure, Culture and Process. Those elements must be analyzed simultaneously and holistically as a system including the cross-cutting among those elements. This is the dynamic of a Social Development toward a better quality of socio-cultural life, not merely a partial material "welfare".

The study on informal sector in Surakarta has showed empirically that the development approach which put emphasis on the element of socio-cultural life is something feasible and viable and not necessarily damaging the economic growth. In Surakarta the mayor Jokowi had started the development with his "inclusive" vision, namely "the prosperity of common people". Based on this some structural development have been constructed accordingly (value based development). It was observed that even though the social development in Surakarta was mostly mobilized by the "structural power" initiated by the government, social development could also happen by its own internal dynamics. The decision to give free stall to the street vendors had improved their self esteem and stimulated some new value systems among them. The rule of non-violence for Satpol PP (Structural element) has produced not only cultural development (non-violent values), but also the growth of "social Process": the new pattern of interactions between the member of Satpol PP and the street vendors. Reversely there are some cases where Government regulations (Structural element) were influenced by the development of Culture and social Process (self- reinforcing process of the basic elements). Observing the cross-cutting areas is very important to see how the structure-culture-process interact and merge one another and how far does the cross-cuttings produced social development (inclusiveness).

The "cross-cutting" analysis is somewhat relevant to Victor Nee's (2005) "the coupling of informal and formal institutions" and the manifestation of what Giddens (1984) called "the duality of structure". Basically Giddens's structuration is parallel with the concept of "Process". This article, hence argue that sociological analysis must holistically cover the dynamic and systemic self reinforcing process between "structure-culture-process" at the same time.

Furthermore, future research must also pay attention to some other aspects of the interconnection among the elements of "structure-culture-process", like for instance "the structure of Structure" (Note 8) (how various regulations are structured, how is the coherence and the consistence to each other),"the culture of Structure" (how existing local culture such as value system and belief system perceive, interpret and give meaning to formal regulations), "the process of Structure"(how the structural forces were processed politically or informally in the field) and so on. We could also explore some potentially important new concepts such as the "structure of Culture", the "process of Culture", the "structure of Process" and the "culture of Process".

Singh and Aspalter (2008) have also offered three elements of Social Development i.e.: "values" (such as neo liberalism, religious hatredism, acceptance of violence etc.), "institutions" (IMF or other welfare institutions), and "practices" (ignorance, corruption, conflict, collaborations etc.). This approach is somewhat in line with what has been offered in this article since it tries to identify the elements of Social Development more "societal" rather than "sectoral". The approach in this article however, is comparatively more sociological, because it uses the concept of Culture instead of values, Structure instead of institutions and Process instead of practices. Hence it could assess the impacts of the development programs straight to the basic elements of socio-cultural life.

Last but not least, to make this approach usable and workable, a construction of an Index of Social Development is needed. A preliminary construction of this index could be seen in Wirutomo (2011) and Hardjosukarto (2012). Only through a measurable instrument, the achievement of a genuine Social Development (on its basic elements: structure-culture-process) could be monitored more accurately.

\section{Concluding Remarks}

Based on research data and a "professional judgment" it could be indicated that Surakarta City has been to some degree practicing "social development". The major criteria is how far the development had impacts on Structure-Culture-Process and how far it was oriented toward socio-cultural inclusiveness.

The value of development isactually lied in its "orientation". The growth-oriented developmentwould only emphasize on "how to enlarge and accelerate the economic output". Social developmentconcerns instead in building the basic elements of people's socio-cultural life i.e.structural development (its bottom line is to equalize the "power relation" in society), cultural development (building inclusive-emansipatory"value system"), social process (the provision of freedoom and opportunityfor each citizen to negotiate their life meaning and aspirations in daily informal interaction and communication).The research findings has shown that Structure-Culture-Process are cross-cutting to each other in various forms, self-reinforcing and producing a synergic and accumulative effect toward a betterment of socio-cultural life. 
Various recent models and approaches of Social Development (e.g. Human Develoment, People Centred Development, MDGs etc.) are indeed important corrections to the existing growth oriented development model; nevertheless their focus is still limited to the promotion and improvement of the so called "social sectors" (education, health gender, poverty etc.),hence they are only targeting to improve sectoral accomplishment, not "societal" one. This article instead, is proposing the quality improvement of the basic element of societal life. As a consequence, social development may not be considered as complimentary and be in conjunction to economic development (Midgley, 1995) but it must become the basis and the root of any sectoral development (including the economic).

Social development in Surakarta from macro-statistical perspective seems still in its infancy but sociologically what has been practiced by Jokowi's administration is containing significant development in term of "structure-culture and process" that are oriented strongly to "inclusiveness". It makes us confidence that Social Development is something feasible and viable.

\section{Acknowledgement}

The researcher would like to thank the Directorate of Research and Community Services in the University of Indonesia for funding the research, by way of 2010 Collaborative Research Grants, entitled: "The Development of Social Development Index for Informal Sector in Cities: Toward the Inclusive Policy for Small Entrepreneur"; and the members of the research team: Linda Darmajanti, Sudarsono Hardjosoekarto, Chotib, Lidya Triana, Wahidah R. Bulan, Sakti and Fajri; as well as field researcher: Dr. Dradjat Tri Kartono and some students at the Department of Sociology, State University at Solo (UNS). The researcher would also like to thank Ms. Nina Sardjunani, the deputy head of Human Resources Division of Bappenas, and Dr. Ritonga senior officer of Indonesian Bureau of Statistics. Dr. Rochman Achwan for his academic advice and Daisy Indira Yasmine for her assistance.

\section{References}

Aspalter, C. (2006). Toward a more people-centered paradigm in social development. Asian Journal of Social Policy, 2(1), 65-86.

Bellah et al. (1992). The Good Society. New York: Alfred A. Knopf Inc.

Bourdieu, P. (1992). An invitation to Reflective Sociology.Chicago, Il: University of Chicago Press.

Bourdieu, P., \& Passeron, J.-C. (1977). Reproduction in Education, Society and Culture. London: Sage.

Conyers, D. (1982). An Introduction to Social Planning in the Third World. Chicester: John Willey and Sons.

Dahrendorf, R. (1959). Class and Class Conflict in Industrial Society. London: Routledge.

Durkheim, E. (1938). The Rules of Sociological Method. New York: Free Press.

Durkheim, E. (1961). The Elementary Forms of Religious Life. New York: Collier Book.

Giddens, A. (1984). The Constitution of Society. Cambridge: Polity.

Giddens, A. (2009). Sociology. Cambridge: Polity Press.

Habermas, J. (1984). The Theory of Communication Action (Vol. 1). London: Heinemann.

Haralambos \& Holborn. (2008). Sociology: Themes and Perspectives. London: Harpers Collins Publisher.

Hardjosoekarto, S. (2012). Construction of Social Development Index as a Theoretical Research Practice in Action Research by Using Soft Systems Methodology. System Practice Action Research, 25(6), 493-509. http://dx.doi.org/10.1007/s11213-012-9237-9.

Hardjosoekarto, S. (2013). Dual Imperatives of Action Research: Lessons From Theoretical Research Practice to Construct Social Development Index by Using Soft Systems Methodology. Human Resource Management Research, Scientific and Academic Publishing, 49-53. http://dx.doi.org/10.5923/j.hrmr.20130301.10

Harrison, L., \& Huntington. (2000). Culture Matters: How Values Shape Human Progress. New York: Basic Book.

Korten, D. C. (1990). Getting to the $21^{\text {st }}$ Century: Voluntary Action and the Global Agenda. Kumarian Press.

Korten, D. C. (2006). The Great Turning. San Fransisco: Berret Koehler Publisher Inc. and Kumarian Press.

Marx, K. (1967/1894). Capital 3 vols. New York: International Publishers.

Midgley, J. (1995). Social Development: The Development Perspective in Social Welfare. London: Sage Publications. 
Midgley, J. (2008). Developmental Social Policy: Theory and Practice. In S. Singh, \& C. Aspalter (Eds.), Debating Sosial Development: Strategies for Social Development. Hongkong: Casa Verde Publishing for the Asian Association for Social Welfare.

Nee, V., \& Swedberg, R. (2005). The Economic Sociology of Capitalism. Princeton: Princeton University Press.

Osborn, D., \& Gaebler, T. (1993). Reinventing Government: How the Entrepreneurial Spirit is Transforming the Public Sector. Plume Publisher.

Parsons, T. (1951). The Social System. Glencoe, Il: Free Press.

Prihantika, I., \& Hardjosukarto, S. (2011). The Causal Map of The Mayor's Policies on Regional Competitiveness. Journal of Administrative Science \& Organization Bisnis \& Birokrasi, 18(1), 339-352.

Singh, S., \& Aspalter, C. (2008). Debating Social Development: Strategies for Social Development. Hongkong: Casa Verde Publishing for the Asian Association for Social Welfare.

Sukamoto. (2003). Social Development, Culture, and Participation: Toward Theorizing Endogenous Development in Tanzania. (Unpublished doctoral dissertation). Graduate School of Asia-Pacific Studies, Waseda University, Japan.

United Nation Development Program. (1997). Human Development Report. New York: Oxford University Press.

Weber, M. (1958). The Protestant Ethic and the Spirit of Capitalism. New York: Charles Scribner's Sons.

Weber, M. (1963). The Sociology of Religion. Boston: Beacon Press.

Wirutomo et al. (2011a). Pengembangan Indeks Pembangunan Sosial bagi Sektor Informal di Kota: Studi Kasus Kota Depok dan Surakarta. Unpublished Research Report. Collaboration Research between Labsosio Department of Sociology University of Indonesia and Depok Local Government.

Wirutomo et al. (2011b). Social Development Policies on Informal Sector in Solo. Journal of Administrative Science \& Organization: Bisnis \& Birokrasi, 18, 92-107.

Wirutomo, P. (2012). Defining Social Development: A case study on Informal sector in Solo. Paper presented in International Seminar "Social Development". Jogyakarta - Indonesia.

\section{Notes}

Note 1. Social interaction refers to more observable dynamics of action and reaction between two or more actors. Social relation refers to a deeper, structural and/or cultural, mostly unobservable power relation between two or more actors. Social interaction is generally less structural or cultural, but more processual, more dynamic and contains more symbolic "transaction" and negotiation.

Note 2. Social sector is usually defined as sector "its input are money, but its output are not money" (such as education, health, religion etc). So that the "development of social sector" is far too narrow than a "Social Development".

Note 3. Even though private business cannot exercise legal enforcement, yet its influence is very effective for controlling public life (through advertisement, commodities, physical infrastructures and facilities, popular lifestyles etc.).

Note 4. Some parts of this report has been published in international Journal of Administrative Sciences: Bisnis \& Birokrasi (vol 18, number 2, May 2011), for this manuscript some revisions have been made accordingly.

Note 5. Surakarta is a Municipal City located in Central Java, this is a middle size city $(45 \mathrm{~km} 2)$ with around half million of population. This City (with the nickname Solo) is one of the most famous historical place where the Palace of Sultan (the king of Surakarta Kingdom) is located.

Note 6. This is called by Victor Nee (2005) as "the coupling of informal and formal institutions".

Note 7. This is a manifestation of Giddens" "duality of structure".

Note 8. Structure with little character has a generic meaning, with capital letter represents a concept with sociological meaning. 


\section{Copyrights}

Copyright for this article is retained by the author(s), with first publication rights granted to the journal.

This is an open-access article distributed under the terms and conditions of the Creative Commons Attribution license (http://creativecommons.org/licenses/by/3.0/). 